\title{
PERAN KEPERCAYAAN MEMEDIASI PENGARUH PENGALAMAN TERHADAP NIAT MENGGUNAKAN KEMBALI JASA JNE DI KOTA DENPASAR
}

\author{
Kadek Dwita Prabandari ${ }^{1}$ \\ Ni Nyoman Kerti Yasa ${ }^{2}$
}

\author{
${ }^{1,2}$ Fakultas Ekonomi dan Bisnis Universitas Udayana, Bali, Indonesia \\ 1e-mail: prabandariujek@gmail.com
}

\begin{abstract}
ABSTRAK
Dalam era globalisasi, perkembangan dunia usaha semakin tidak dapat diprediksi, berbagai usaha di bidang jasa atau produksi semakin bersaing. Kebutuhan konsumen semakin meningkat dan banyak bisnis-bisnis onlineyang bermunculan. Bisnis jasa saat ini sangat dibutuhkan dan berpengaruh dalam aktivitas konsumen sehari-hari. Banyak sekali perusahaan jasa pengiriman barang yang mudah ditemukan disetiap sudut kota dan diantarannya adalah JNE, Tiki, Pos Indonesia, dan DHL. Jasa pengiriman barang yang digunakan dalam penelitian ini adalah JNE. Lokasi penelitian ini dilakukan di Kota Denpasar pada kecamatan Denpasar Barat, Denpasar Selatan, Denpasar Timur, dan Denpasar Utara. Ukuran sampel dalam penelitian ini adalah 100 sampel, dipilihnya 100 responden karena dalam penelitian ini menggunakan metode path analysis dimana daalam metode tersebut harus menggunakan minimal 100 sampel. Hasil dari penelitian ini adalah pengalaman berpengaruh positif dan signifikan terhadap kepercayaan, pengalaman berpengaruh positif dan signifikan terhadap niat menggunakan kembali, kepercayaan berpengaruh positif dan signifikan terhadap niat menggunakan kembali, kepercayaan mampu memediasi pengaruh pengalaman terhadap niat menggunakan kembali jasa JNE di Kota Denpasar.
\end{abstract}

Kata Kunci: pengalaman, kepercayaan, niat menggunakan kembali.

\begin{abstract}
In the era of globalization, the development of the business world increasingly unpredictable, various businesses in the field of service or production increasingly competitive. Consumer needs are increasing and many online businesses are emerging. Business services today are needed and influential in the activities of everyday consumers. Many freight forwarder companies are easily found in every corner of the city and include JNE, Tiki, Pos Indonesia, and DHL. The freight service used in this research is JNE. The location of this research was conducted in Denpasar City in subdistrict of West Denpasar, South Denpasar, East Denpasar, and North Denpasar. Sample size in this research is 100 samples, choose 100 responden because in this research using path analysis method where daalam method must use at least 100 sample. The result of this research is experience having positive and significant effect to trust, experience have positive and significant effect to reuse intention, trust have positive and significant effect to intention of reuse, trust able to mediate influence of experience to intention to reuse JNE service in Denpasar City.
\end{abstract}

Keywords: experience, trust, intention of reuse. 


\section{PENDAHULUAN}

Dalam era globalisasi, perkembangan dunia usaha semakin tidak dapat diprediksi, berbagai usaha di bidang jasa atau produksi semakin bersaing (Nurhayati, 2012). Kebutuhan konsumen semakin meningkat dan banyak bisnisbisnis onlineyang bermunculan. Konsumen dapat berbelanja atau melakukan aktivitasnya sehari-hari secara online (Widiyanto, 2015). Dengan demikian, aktivitas yang dilakukan akan didapatdengan cara yang mudah dan praktis. Hal tersebut cukup membantu perkembangan perekonomian masyarakat Indonesia. Menurut Noeraini dan Sugiyono (2016), bisnis jas a saat ini sangat dibutuhkan dan berpengaruh dalam aktivitas konsumen sehari-hari. Banyak sekali perusahaan jasa pengiriman barang yang mudah ditemukan disetiap sudut kota dan diantarannya adalah JNE, Tiki, Pos Indonesia, dan DHL (Sinulingga, 2012). Hal ini mengakibatkan konsumen memiliki banyak pilihan untuk memilih tempat jasa kurir pengiriman barang yang tepat dan dapat dipercaya oleh konsumen dan juga memberikan pelayanan terbaik dengan harga yang terjangkau sehingga memudahkan kegiatan konsumen dalam hal pendistribusian barang dengan jarak jauh dapat tersalurkan dengan baik (Noeraini dan Sugiyono, 2016).

Melihat peluang bahwa manusia kini ingin berbagai hal yang mudah dan praktis, muncullah sebuah gagasan bisnis jasa bernama JNE(Astarina et al., 2017). JNE adalah perusahaan jasa kurir yang bergerak dalam bidang pengiriman paket dan logistik dalam wilayah lokal maupun internasional yang didukung secara online. JNE memperluas pengembangan produk dan pelayanan yang diberikan, antara lain menyediakan jasa kurir ekspres domestik (Diplomat, Super Speed / SS, 
Kadek Dwita Prabandari, Peran Kepercayaan Memediasi...

Yakin Esok Sampai / One Day Service, Regular, Ongkos Kirim Ekonomis), logistik, distribusi, money remittance (transfer uang), trucking air \& sea cargo (pengiriman barang melalui pesawat dimana bagasinya digunakan JNE), escort (jasa penjemputan bandara), hingga customer clearance (jasa kapabean), menurut Noeraini dan Sugiyona (2016). JNE muncul dari adanya kebutuhan akan pemenuhan gaya hidup praktis dan mudah yang semakin marak dewasa ini. Mengingat kesibukan masing-masing orang yang semakin bertambah, menyebabkan kurangnya waktu yang diluangkan untuk melakukan kegiatan yang dianggap kurang praktis. Saat ini JNE menjadi salah satu solusi utama dalam berbagai kegiatan sehari-hari. JNE merupakan suatu perusahaan yang mempelopori revolusi atau perubahan pada sistem jasa pengiriman barang.Dengan kecanggihan teknologi yang ada saat ini, banyak bisnis-bisnis online yang memanfaatkan adanya jasa kurir tesebut sehingga konsumen praktis dalam berbelanja (Astarina et al., 2017).

Dikutip dari website jne.co.id pada Bulan Maret, peluang yang terus tumbuh ini mendorong JNE untuk terus memperluas jaringannya ke seluruh kota besar di Indonesia. Saat ini titik-titik layanan JNE telah mencapai diatas 6.000 lokasi dan masih terus bertambah dengan jumlah karyawan lebih dari 40.000 orang.Lebih dari 150 lokasi JNE telah terhubungkan dengan sistem komunikasi online, dikawal oleh sistem dan akses situs informasi yang efektif serta efisien bagi konsumen dalam upaya mengetahui status terkini pengiriman paket atau dokumen. Menurut Astarina et al. (2017), kecepatan dan kehandalan layanan yang konsisten dan bertanggung jawab membuat kredibilitas JNE semakin tinggi di 
mata pelanggan maupun mitra kerja.Seiring dengan peningkatan investasi asing, pertumbuhan ekonomi dalam negeri, dan perkembangan teknologi informasi serta beragam inovasi produk yang dikembangkan, kinerja JNE semakin tumbuh juga berkembang di kalangan dunia usaha maupun masyarakat Indonesia. Jalur Nugraha Ekakurir atau yang biasa disebut JNE berdiri pada tahun 1990. Sejak awal berdiri JNE telah banyak melakukan strategi pemasaran. JNE telah berhasil menanamkan pengalaman dan keprcayaan yang baik di dalam benak konsumen sehingga membuat konsumen melakukan pembelian ulang, hal ini dapat dilihat dari hasil survei dari Top Brand Award kategori service pada Tabel 1.

Tabel 1.

Top Brand Fase 2 Kategori Service 2017

\begin{tabular}{ccc}
\hline Merek & $\begin{array}{c}\text { TBI } \\
\text { Persentase (\%) }\end{array}$ & Top \\
\hline JNE & 49,4 & Top \\
Tiki & 34,7 & Top \\
Pos Indonesia & 8,4 & \\
DHL & 1,3 & \\
\hline
\end{tabular}

Sumber : Top Brand Award, 2017

Tabel 1 menunjukkan bahwan JNE dan Tiki menempati posisi Top Brand dimana JNE menduduki peringkat pertama dan Tiki pada peringkat kedua yang selanjutnya diikuti oleh Pos Indonesia pada posisi ketiga dan DHL menempati posisi terakhir. Dari data tersebut menerangkan bahwa JNE menyadari pentingnya tingkat kesadaran masyarakat yang tinggi pada kepercayaan dari jasa service perusahaan. Selain selalu berusaha untuk memeberikan yang terbaik untuk pelanggannya JNE juga mampu memberikan pengalaman yang baik pada konsumennya sehingga JNE mengalahkan pesaingnya seperti TIKI, Pos Indonesia, dan DHL di awal 2017. Setelah munculnya kepercayaan yang tinggi 
Kadek Dwita Prabandari, Peran Kepercayaan Memediasi...

dan pengalaman yang baik di benak konsumen, maka akan membuat konsumen memiliki niat menggunakan kembali. Menurut Mayer dan Schwager (2007), mengatakan "Merek yang sukses membentuk pengalaman pelanggan dengan menanamkan proposisi nilai fundamental dalam berbagai fitur penawaran". Pengalaman merupakan elemen utama dari kehidupan konsumen, bagi konsumen mengkonsumsi tidak hanya melahap atau menggunakan produk atau jasa, melainkan perlu adanya pengalaman yang berkesan dalam mengkonsumsi (Prastyaningsih et al., 2014).

Dalam persaingan bisnis era modern, kepercayaan masyarakat terhadap suatu merek atau perusahaan merupakan hal yang begitu diperlukan dalam bisnis (Rizanata, 2014). Konsumen yang puas akan memiliki kepercayaan yang tinggi pada perusahaan dan tidak akan berpindah ketempat lain, bahkan ikut mempromosikan tempat tersebut kepada saudara, teman, dan lingkungan sekitarnya, agar calon konsumen lain menggunakan jasa perusahaan tersebut yang sudah dipercayai oleh pelanggannya. Kepercayaan adalah ekspektasi yang dipegang oleh individu bahwa ucapan seseorangdapat diandalkan. Membangun kepercayaan terhadap konsumen bukanlah suatu pekerjaan yang mudah dalam kondisi persaingan yang semakin tajam. Kepercayaan konsumen terhadap perusahaan jasa dikarenakan perusahaan tersebut dikenal dan telah memiliki nama yang baik di kalangan masyarakat, kejujuran para karyawannya serta mampu menepati janji sehingga tumbuhnya rasa senang dari konsumen yang membuat timbulnya kepercayaan kepada perusahaan. Adanya bentuk perhatian dan motivasi 
dari pihak perusahaan yang dipercaya untuk bertindak sesuai dengan kepentingan konsumen yang mempercayai perusahaan (Dizaet al., 2016).

Pengalaman penggunaan jasa atau produk akan membentuk penilaian konsumen akan jasa atau produk tersebut baik itu penilaian akan kualitas pelayanan, kemudahan akses, dan sebagainya. Penilaian tersebut, nantinya akan terbentuk kepercayaan akan produk atau jasa yang telah dirasakan sebelumnya. Pengalaman merupakan elemen utama dari kehidupan konsumen, bagi konsumen mengkonsumsi tidak hanya melahap atau menggunakan produk atau jasa, melainkan perlu adanya pengalaman yang berkesan dalam mengkonsumsi (Prastyaningsih et al., 2014).Pengalaman yang dirasakan ketika mengkonsumsi suatu produk atau jasa juga menjadi pertimbangan konsumen saat ini dalam memilih produk atau jasa yang ingin dikonsumsi berikutnya (Pramudita dan Japarianto, 2013).

Kepercayaan dan pengalaman merupakan sebagian dari indikator yang digunakan dalam mengukur niat menggunakan atau niat membeli kembali konsumen, dengan adanya kepercayaan dan pengalaman yang baik dalam menggunakan jasa atau produk, maka konsumen diharapkan akan melakukan penggunaan kembali atas jasa tersebut. Minat beli ulang yang tinggi mencerminkan tingkat kepuasan yang tinggi dari konsumen ketika memutuskan untuk mengkonsumsi suatu produk. Minat beli ulang ini timbul setelah konsumen mendapatkan kepuasan terhadap suatu produk atau jasa tertentu sehingga konsumen memiliki keinginan atau minat untuk mengkonsumsi atau melakukan pembelian kembali, dengan adanya minat beli ulang yang terus-menerus, maka 
Kadek Dwita Prabandari, Peran Kepercayaan Memediasi...

dapat diartikan bahwa konsumen tersebut telah menjadi seorang pelanggan yang loyal terhadap produk atau jasa tertentu(Astarina et al., 2017).

Menurut Nurhayati dan Murti (2012), minat pembelian ulang adalah keinginan dan tindakan konsumen untuk membeli ulang suatu produk karena adanya kepuasan yang diterima sesuai yang dinginkan dari suatu produk. Merek yang sudah melekat dalam hati pelanggan akan menyebabkan pelanggan melanjutkan pembelian atau pembelian ulang. Minat beli ulang merupakan bagian dari perilaku pembelian yang selanjutnya akan membentuk loyalitas dalam diri konsumen. Kesesuaian performa produk dan jasa yang ditawarkan dengan yang diharapkan konsumen akan memberikan kepuasan dan akan menghasilkan minat beli ulang konsumen di waktu yang akan datang. Dapat dijelaskankan bahwa minat beli ulang adalah sebuah minat dari seorang konsumen untuk melakukan pembelian atau penggunaan kembali sebuah produk atau jasa diakibatkan pengalaman positif yang didapat setelah menggunakan produk atau jasa tersebut. Konsumen yang merasa senang dan puas akan suatu barang atau jasa yang telah dibelinya sehingga akan berpikir untuk melakukan pembelian ulang kembali terhadap barang atau jasa tersebut. Konsumen yang mengalami kepuasan setelah melakukan pembelian mempunyai kemungkinan tidak akan merubah pilihannya dengan tidak mencari alternatif merek lain pada pembelian berikutnya (Ardhanari, 2008).

Pengalaman masa lalu memegang peranan penting dalam keputusan pembelian ulang konsumen. Menurut Giantari et al. (2013), pengalaman membeli secara online memiliki pengaruh positif dan signifikan terhadap kepercayaan. Hal 
serupa juga didapat dari hasil penelitian yang dilakukan oleh Parastanti et al., (2014), Suandana (2016), dan Mohmed et al. (2013),yang sama-sama menunjukkan pengalamanmemiliki pengaruh positif dan signifikan terhadap kepercayaan yang berarti bahwa pengalaman yang baik dalam mengonsumsi suatu produk atau jasa akan berpengaruh pada semakin tingginya tingkat kepercayaan konsumen.

$\mathrm{H}_{1}$ : Pengalaman berpengaruh positif dan signifikan terhadap kepercayaan.

Menurut Weisberg et al. (2011) dan Mohmed et al. (2013), pengalaman membelisebelumnyasecaraonlineterkait dengan niat membeli kembali secara online mempunyai pengaruh positif dan signifikan,tidak hanya dipengaruhi oleh kepercayaan dan perilaku sosial. Penelitian yang dilakukan oleh Kusumawati dan Sutopo (2013), menunjukkan bahwa customer experience berpengaruh positif dan signifikan terhadap minat beli ulang konsumen, hal serupa juga ditunjukkan dalam penelitian yang dilakukan oleh Adytia dan Yuniawati (2015) dan Suandana (2016), yang sama-sama menunjukkan bahwa semakin baik pengalaman yang dirasakan oleh konsumen, maka semakin besar pula kemungkinan untuk melakukan pembelian ulang.

$\mathrm{H}_{2}$ : Pengalaman berpengaruh positif dan signifikan terhadap niat menggunakan kembali.

Kepercayaan dibentuk melalui kejujuran vendor website, keamanan data pribadi, dan jaminan pembayaran (Parastanti dkk., 2014). Dalam penelitian sebelumnya juga menunjukkan bahwa bahwa kepercayaan berpengaruh positif dan signifikan terhadap niat membeli kembali (Chinomona dan Dubihlela, 2014; 
Kadek Dwita Prabandari, Peran Kepercayaan Memediasi...

Giantari dkk., 2013; Mohmed et al., 2013; Mosavi and Ghaedi, 2012; Razak et al., 2014; Rose et al., 2012; Thamizhvanan and Xavier, 2013).

$\mathrm{H}_{3}$ : Kepercayaan berpengaruh positif dan signifikan terhadap niat menggunakan kembali.

Weisberg et al.(2011), menemukan bahwa kepercayaan adalah sebagai variabel yang dapat memediasi hubungan pengalaman pembelian terhadap niat membeli kembali secara online. Menurut Maria Eugenia (2009) dan Setiawan Putra dan Suryani (2015) dan Brakus et al. (2009) kepercayaan berpengaruh positif dan signifikan terhadap perilaku pembelian kembali. Hasil tersebut sejalan dengan hasil penelitian yang dilakukan oleh Giantari et al. (2013) dan Suandana (2016), yang menyampaikan bahwa kepercayaan sebagai mediasi sempurna dalam pengalaman dan niat pembelian secara online. Hal tersebut berarti bahwa semakin baik pengalaman, maka semakin tinggi pula tingkat kepercayaan, dimana hal ini dapat meningkatkan niat menggunakan kembali.

$\mathrm{H}_{4}$ : Kepercayaan secara signifikan memediasi pengaruh pengalaman terhadap niat menggunakan kembali.

\section{METODE PENELITIAN}

Obyek dalam penelitian ini adalah pengaruh pengalaman terhadap niat menggunakan kembali yang dimediasi oleh peran kepercayaan pada konsumen jasa JNE di Kota Denpasar. Populasi dalam penelitian ini adalah masyarakat Kota Denpasar yang sudah pernah menggunakan jasa JNE dalam periode waktu satu tahunterakhirdengan jumlah populasi yang pasti terdata dan tidak terbatas (infinite). 
Dalam penelitian ini sampel diambil dengan teknik non probability sampling, yaitu teknik yang memberi peluang sama kepada anggota populasi untuk dipilih menjadi ukuran sampel.Cara demikian sering disebut dengan random samplinh, atau cara pengambilan sampel secara acak. Ukuran sampel dalam penelitian ini adalah 100 sampel. Menurut Sugiyono (2017: 156) untuk memperoleh hasil yang baik ukuran sampel respondenyang diambil untuk mengisi kuesioner dapat ditentukan paling sedikit 5-10 kali jumlah indikator yang diteliti. Penilaian ini menggunakan 10 indikator sehingga dengan menggunakan estimasi berdasarkan jumlah parameter diperoleh ukuran sampel sebesar 50-100 responden. Jumlah dari sampel responden yang akan diuji di dapat dari hasi perhitungan yakni:

Jumlah Responden $=10$ indikator $\mathrm{x} 10=100$ responden

Dipilihnya 100 responden karena dalam penelitian ini menggunakan metode path analysis dimana daalam metode tersebut harus menggunakan minimal 100 sampel. Menurut Roscoe dalam Sekarna (2003) parameter sampel yang baik adalah sekitar 70-140 sampel. Jadi, dengan dipilihnya 100 responden artinya sudah sesuai dengan kriteria yang ditentukan.

Teknik pemilihan sampel menggunakan teknik purposie sampling, yaitu penentuan sampel berdasarkan pertimbangan maupun syarat-syarat yang telah ditentukan. Adapun pertimbangan yang digunakan dalam pengambilan sampel adalah sebagai berikut:

1) Responden berdomisili di Kota Denpasar.

2) Responden memiliki pendidikan minimal SMA/SMK/Sederajat. 
Kadek Dwita Prabandari, Peran Kepercayaan Memediasi...

3) Responden sudah pernah menggunakan jasa JNE minimal sekali dalam waktu satu tahun terakhir.

Dalam penelitian ini teknik analisis yang digunakan yaitu teknik analsis jalur atau yang disebut dengan Path Analysis. Ghozali (2013:249), mendefinisikan analisis jalur (Path Analysis) adalah perluasan dari analisis regresi linear berganda dalam memperkirakan hubungan kausalitas antara variabel yang telah ditetapkan sebelumnya berdasarkan teori. Riduwan dan Kuncoro (2011:2) menyatakan analisis jalur digunakan untuk menganalisis pola hubungan antar variabel dengan tujuan untuk mengetahui pengaruh langsung maupu tidak langsung seperangkat variabel bebas (eksogen) terhadap variabel terikat (endogen). Dasar perhitungan koefisien jalur adalah analisis korelasi dan regresi dan dalam perhitungan menggunakan software dengan program SPSS for windows.

Pengujian hipotesis mediasi dapat dilakukan dengan prosedur yang dikembangkan oleh Sobel (1982) dan dikenal dengan Uji Sobel (Sobel Test). Uji Sobel digunakan dengan menguji kekuatan pengaruh tidak langsung variabel pengalaman $(\mathrm{X})$ terhadap variabel niat menggunakan kembali $\left(\mathrm{Y}_{2}\right)$ melalui variabel kepercayaan $\left(\mathrm{Y}_{1}\right)$. Pengaruh tidak langsung variabel pengalaman $(\mathrm{X})$ terhadap variabel niat menggunakan kembali $\left(\mathrm{Y}_{2}\right)$ melalui variabel kepercayaan $\left(\mathrm{Y}_{1}\right)$ dihitung dengan cara mengalikan koefisien jalur $\mathrm{X}$ terhadap $\mathrm{Y}_{1}$ (a) dengan koefisien jalur $\mathrm{Y}_{1}$ terhadap $\mathrm{Y}_{2}(\mathrm{~b})$ atau $\mathrm{ab}$. Standar error koefisien a dan $\mathrm{b}$ ditulis dengan $\mathrm{S}_{\mathrm{a}}$ dan $\mathrm{S}_{\mathrm{b}}$, besarnya standar error tidak langsung (indirect effect) $\mathrm{S}_{\mathrm{ab}}$. 


\section{HASIL PENELITIAN DAN PEMBAHASAN}

Jumlah responden dalam penelitian ini adalah 100 orang. Seluruh responden yang memberikan tanggapan pada kuesioner dari penelitian ini telah memenuhi kriteria-kriteria yang ditetapkan dalam kriteria responden penelitian yaitu diantaranya berdomisili di Kota Denpasar, berpendidikan minimal SMA/Sederajat, dan pernah menggunakan jasa JNE dalam waktu satu tahun terakhir. Karakteristik responden disajikan pada Tabel 2.

Tabel 2.

\section{Profil Responden}

\begin{tabular}{llcc}
\hline \multicolumn{1}{c}{ Variabel } & \multicolumn{1}{c}{ Klasifikasi } & Jumlah (Orang) & $\begin{array}{c}\text { Persentase } \\
(\%)\end{array}$ \\
\hline Jenis Kelamin & Laki-laki & 40 & 40 \\
& Perempuan & 60 & 60 \\
Usia (Tahun) & Jumlah & 100 & 100 \\
& $17-20$ & 14 & 14 \\
& $21-30$ & 82 & 82 \\
& $>30$ & 4 & 4 \\
Pendidikan Terakhir & Jumlah & 100 & 100 \\
& SMA/Sederajat & 49 & 49 \\
& Perguruan Tinggi & 51 & 51 \\
& Jumlah & 100 & 100 \\
\hline
\end{tabular}

Sumber: Data diolah, 2018

Tabel 2 menunjukan bahwa responden dengan jenis kelamin perempuan lebih banyak dalam melakukan penggunaan jasa JNE dengan persentase 60 persen diikuti dengan responden berjenis laki-laki dengan persentase 40 persen. Responden terbanyak dalam kategori usia adalah 21-30 tahun dengan persentase sebesar 82 persen dikarenakan pada rentang usia ini responden dianggap lebih membutuhkan atau menggunakan jasa JNE. Peringkat kedua ditempati pada usaia 17-20 tahun dengan persentase 14 persen. Peringkat terakahir ditempati pada usia $>30$ tahun dengan persentase 4 persen. 
Kadek Dwita Prabandari, Peran Kepercayaan Memediasi...

Pendidikan terakhir juga diperlihatkan pada Tabel 2 yang memperlihatkan bahwa responden didominasi oleh perguruan tinggi dengan persentase 51 persen dan pada kategori pendidikan terakhir SMA/sederajat memiliki persentase sebesar 49 persen.

Hal ini mengindikasikan bahwa pendidikan terakhir pada perguruan tinggi lebih membutuhkan atau menggunakan jasa JNE.

Uji validitas dilakukan untuk memeriksa apakah pengukuran indicator penelitian sudah tepat di dalam instrument penelitian yang berupa kuesioner. Instumrn dapat dikatakan valid apabila instrument yang digunakan dapat mengukur apa seharusnya diukur. Hasil uji validitas tunjukan pada Tabel 3.

Tabel 3.

Uji Validitas Instrumen

\begin{tabular}{|c|c|c|c|}
\hline Variabel & Instrumen & $\begin{array}{l}\text { Koefisien } \\
\text { Kolerasi }\end{array}$ & Keterangan \\
\hline & $\begin{array}{l}\text { Saya mendapatkan informasi saat menggunakan } \\
\text { jasa JNE }\left(X_{.1}\right)\end{array}$ & 0,765 & Valid \\
\hline \multirow[t]{3}{*}{ Pengalaman } & $\begin{array}{l}\text { Saya memiliki pengalaman yang menyenangkan } \\
\text { saat menggunakan jasa JNE }\left(X_{.2}\right)\end{array}$ & 0,805 & Valid \\
\hline & $\begin{array}{l}\text { Saya merasakan kemudahan transaksi saat } \\
\text { penggunaan jasa JNE }\left(\mathrm{X}_{\cdot 3}\right)\end{array}$ & 0,844 & Valid \\
\hline & $\begin{array}{l}\text { Saya percaya merasa aman telah menggunakan } \\
\text { jasa JNE }\left(\mathrm{Y}_{1.1}\right)\end{array}$ & 0,856 & Valid \\
\hline \multirow[t]{3}{*}{ Kepercayaan } & $\begin{array}{l}\text { Saya percaya saat menggunakan jasa JNE } \\
\text { merasa jauh lebih mudah }\left(\mathrm{Y}_{1.2}\right)\end{array}$ & 0,808 & Valid \\
\hline & $\begin{array}{l}\text { Saya percaya kepada jasa JNE secara } \\
\text { menyeluruh }\left(\mathrm{Y}_{1.3}\right)\end{array}$ & 0,718 & Valid \\
\hline & Saat puas saaat menggunakan jasa JNE $\left(\mathrm{Y}_{1.4}\right)$ & 0,781 & Valid \\
\hline Niat & $\begin{array}{l}\text { Saat saya membutuhkan, saya akan } \\
\text { menggunakan kembali jasa JNE }\left(\mathrm{Y}_{2.1}\right)\end{array}$ & 0,754 & Valid \\
\hline Menggunakan & Saya tidak akan berpindah dari jasa JNE $\left(\mathrm{Y}_{2.2}\right)$ & 0,879 & Valid \\
\hline Kembali & $\begin{array}{l}\text { Saya tetap memilih jasa JNE untuk di masa } \\
\text { depan }\left(Y_{2.3}\right)\end{array}$ & 0,908 & Valid \\
\hline
\end{tabular}

Hasil uji validitas pada Tabel 3 menunjukan seluruh variabel memiliki nilai koefisien dengan skor total sekuruh item pernyataan lebih bedar dari 0,30 . Hal ini menunjukan bahwa pernyataan dalam instrument penelitian valid. 
Uji reliabilitas dilakukan untuk mengetahui adanya konsistensi alat ukur dalam penggunanya. Instrument dapatdikatakan reliabel bila digunakan beberapa kali untuk mengukur obyek yang sama, maka akan menghasilkan data yang sama. Hasil uji reliabilitas ditunjukan pada Tabel 4.

Tabel 4.

Uji Reliabilitas Instrumen

\begin{tabular}{lcc}
\multicolumn{1}{c}{ Variabel } & Cronbach's Alpha & Keterangan \\
\hline Pengalaman & 0,728 & Reliabel \\
Kepercayaan & 0,801 & Reliabel \\
Niat Menggunakan Kembali & 0,807 & Reliabel \\
\hline
\end{tabular}

Sumber: Data diolah, 2018

Tabel 4 menunjukan bahwan semua variable yang digunakan dalam penelitian ini telah memenuhi syarat konsistensi meupun keandalan data. Keseluruhan variable memiliki cornbach's alpha lebih dari 0,70yang berarti bahwa seluruh indikator variable dalam penelitian ini adalah reliabel, sehingga dapat digunakan sebagai instrument penelitian.

Perhitungan koefisien path dilakukan dengan analisis regresi melalui software SPSS 18.0 for Windows, dengan perolehan hasil yang disajikan pada tabel 5 .

Tabel 5.

Hasil Analisis Jalur Persamaan Regresi 1

\begin{tabular}{cccccc}
\hline Model & \multicolumn{2}{c}{$\begin{array}{c}\text { Unstandardized } \\
\text { Coefficients } \\
\text { B }\end{array}$} & $\begin{array}{c}\text { Standardized } \\
\text { Coefficients } \\
\text { Beta }\end{array}$ & t & Sig. \\
\hline 1 (Constant) & 7.131 & 1.385 & & 5.149 & \\
Pengalaman & .733 & .114 & .544 & 6.412 & .000 \\
R1 Square & & & & & 0,296 \\
F Statistik & & & & & 41,116 \\
Signifikansi & & & & 0,000 \\
\hline
\end{tabular}

Sumber : Data diolah, 2018

B 
Kadek Dwita Prabandari, Peran Kepercayaan Memediasi...

Berdasarkan hasil analisis jalur substruktur 1 pada Tabel 4.8, maka persamaan strukturalnya adalah sebagai berikut :

$$
\begin{aligned}
& \mathrm{Y} 1=\beta_{1} \mathrm{X}+\varepsilon_{1} \ldots \\
& \mathrm{Y} 1=0,544 \mathrm{X}+\varepsilon_{1}
\end{aligned}
$$

Nilai $\beta_{1}$ adalah sebesar 0,544 memiliki arti bahwa pengalaman berpengaruh positif terhadap kepercayaan, dengan kata lain jika faktor pengalaman maka akan mengakibatkan peningkatan pada kepercayaan jasa JNE sebesar 0,544

\section{Tabel 6}

\begin{tabular}{|c|c|c|c|c|c|}
\hline \multirow[t]{2}{*}{ Model } & \multicolumn{2}{|c|}{$\begin{array}{l}\text { Unstandardized } \\
\text { Coefficients }\end{array}$} & \multirow{2}{*}{$\begin{array}{c}\text { Standardized } \\
\text { Coefficients } \\
\text { Beta }\end{array}$} & \multirow[t]{2}{*}{$\mathbf{t}$} & \multirow[t]{2}{*}{ Sig. } \\
\hline & B & Std.Error & & & \\
\hline 1 (Constant) & .489 & 1.232 & & .397 & .692 \\
\hline Pengalaman & .307 & .107 & .253 & 2.862 & .005 \\
\hline Kepercayaan & .461 & .080 & .511 & 5.781 & .000 \\
\hline R1 Square & & & & & 0,466 \\
\hline F Statistik & & & & & 42,299 \\
\hline Signifikansi & & & & & 0,000 \\
\hline
\end{tabular}

Hasil Analisis Jalur Persamaan Regresi 2

Sumber : Data diolah, 2018

Berdasarkan hasil analisis jalur substruktur 2 pada Tabel 6, maka persamaan strukturalnya adalah sebagai berikut :.

$$
\begin{aligned}
& \mathrm{Y} 2=\beta_{2} \mathrm{X}+\beta_{4} \mathrm{Y} 1+\varepsilon_{2} \ldots \ldots \ldots \\
& \mathrm{Y} 2=0,253 \mathrm{X}+0,511 \mathrm{Y} 1+\varepsilon_{2}
\end{aligned}
$$

Berdasarkan persamaan tersebut maka dapat disimpulkan bahwa Nilai $\beta_{2}$ adalah sebesar 0,253 memiliki arti bahwa pengalaman berpengaruh positif terhadap niat menggunakan kembali, dengan kata lain jika faktor pengalaman meningkat maka akan mengakibatkan peningkatan pada niat menggunakan 
kembali jasa JNE sebesar 0,253. Nilai $\beta_{ \pm}$adalah sebesar 0,511 memiliki arti bahwa kepercayaan berpengaruh positif terhadap niat menggunakan kembali, dengan kata lain jika faktor kepercayaan meningkat maka akan mengakibatkan peningkatan pada niat menggunakan kembali jasa JNE sebesar 0,511.

Pengaruh langsung (dirrect effect) Pengaruh variabel pengalaman (X) terhadap kepercayaan $\left(\mathrm{Y}_{1}\right)$ adalah sebesar $\beta_{1}=0,544$, Pengaruh variabel pengalaman $(\mathrm{X})$ terhadap variabel niat menggunakan kemabli $\left(\mathrm{Y}_{2}\right)$ adalah sebesar $\beta_{2}=0,253$. Pengaruh variabel kepercayaan $\left(Y_{1}\right)$ terhadap niat menggunakan kembali $\left(\mathrm{Y}_{2}\right)$ adalah sebesar $\beta_{3}=0,511$.

Pengaruh tidak langsung (indirect effect) Pengaruh variabel pengalaman (X) terhadap niat menggunakan kembali $\left(\mathrm{Y}_{2}\right)$ dengan kepercayaan $\left(\mathrm{Y}_{1}\right)$ sebagai variabel perantara:

$$
\begin{aligned}
\text { indirect effect } & =\beta_{1} \times \beta_{3} \ldots \ldots \ldots \ldots \ldots \ldots \ldots \ldots \ldots \ldots \ldots \ldots \ldots \ldots \ldots \ldots \ldots \ldots \ldots \ldots \ldots \ldots \\
& =0,544 \times 0,511 \\
& =0,277
\end{aligned}
$$

Pengaruh total (total effect) Total pengaruh variabel pengalaman (X) terhadap niat menggunakan kembali $\left(\mathrm{Y}_{2}\right)$ melaluivariabel kepercayaan $\left(\mathrm{Y}_{1}\right)$ sebagai berikut :

$$
\begin{array}{ll}
\text { total effect } & =\beta_{2}+\left(\beta_{1} \times \beta_{3}\right) \ldots \ldots \ldots \ldots \ldots \\
& =0,253+(0,544 \times 0,511) \\
& =0,530
\end{array}
$$

Menguji nilai koefisien determinasi $\left(\mathrm{R}^{2}\right)$ dan variabel error (e). Berdasarkan model substruktur 1 dan substruktur 2, maka dapat disusun model diagram jalur 
Kadek Dwita Prabandari, Peran Kepercayaan Memediasi...

akhir. Sebelum menyusun model diagram jalur akhir, terlebih dahulu dihitung nilai standar error sebagai berikut:

$$
\begin{aligned}
& P e_{i}=\sqrt{ } 1-R_{1}^{2} \\
& \text { Pei }=\sqrt{ } 1-R_{1}{ }^{2}=\sqrt{ } 1-0,330=\sqrt{ } 1-0,296=0,839 \\
& \operatorname{Pe} 2=\sqrt{1}-\mathrm{R}_{2}{ }^{2}=\sqrt{ } 1-0,466=0,730
\end{aligned}
$$

Berdasarkan perhitungan pengaruh error (Pei), didapatkan hasil pengaruh error $\left(\mathrm{Pe}_{1}\right)$ sebesar 0,839 dan pengaruh error $\left(\mathrm{Pe}_{2}\right)$ sebesar 0,730. Hasil koefisien determinasi total adalah sebagai berikut:

$$
\begin{aligned}
\mathrm{R}^{2}{ }_{\mathrm{m}} & =1-\left(\mathrm{Pe}_{1}\right)^{2}\left(\mathrm{Pe}_{2}\right)^{2} \ldots \ldots \\
& =1-(0,839)^{2}(0,730)^{2} \\
& =1-(0,703)(0,532) \\
& =1-0,626=0,374
\end{aligned}
$$

Nilai determinasi total sebesar 0,374 mempunyai arti bahwa sebesar $37,4 \%$ variasi niat menggunakan kembalidipengaruhi oleh variasi pengalaman dan kepercayaan, sedangkan sisanya sebesar $62,6 \%$ djelaskan oleh faktor lain yang tidak dimasukkan ke dalam model.

Uji Sobel merupakan alat analisis yang digunakan untuk menguji signifikansi dari hubungan tidak langsung antara variabel independen dengan variabel dependen yang dimediasi oleh variabel mediator. Uji Sobel dirumuskan dengan persamaan berikut dan dapat dihitung dengan menggunakan aplikasi Microsoft Excel 2007. Langkah-langkah yang digunakan dalam pengujian variabel mediasi ( Uji Sobel) antara lain: 
Pengambilan keputusan dalam pengujian hipotesis dalam penelitian ini adalah:

$\mathrm{H}_{0} \quad$ : Kepercayaan bukan sebagai variabel mediasi variabel kredibilitas Pengalaman terhadap niat menggunakan kembali.

$\mathrm{H}_{1} \quad$ : Kepercayaan sebagai variabel mediasi variabel kredibilitas pengalaman terhadap niat menggunakan kembali.

Menentukan Daerah Kritis Taraf nyata alpha 0,05 dan Z tabel 1,96 merupakan kriteria pengujian yang dinyatakan sebagai berikut: $\mathrm{Z}$ hitung $\leq \mathrm{Z}$ tabel, maka $\mathrm{H}_{0}$ diterima yang berarti $\mathrm{Y}_{1}$ bukan sebagai variabel mediasi. $\mathrm{Z}$ hitung $>\mathrm{Z}$ tabel, maka $\mathrm{H}_{0}$ ditolak yang berarti $\mathrm{Y}_{1}$ merupakan variabel mediasi.

Penghitungan Variabel Mediasi Menggunakan Statistik Uji sobel dihitung dengan rumus sebagai berikut :

$$
\begin{aligned}
& \mathrm{Z}=\quad \mathrm{ab} \\
& \overline{b^{2} \mathrm{Sa}^{2}+\mathrm{a}^{2} \mathrm{Sb}^{2}+\mathrm{Sa}^{2} \mathrm{Sb}^{2}} \\
& \operatorname{Sig}=(1-\operatorname{NORMDIST}(Z))+2)) \\
& \mathrm{a}=0,544 \\
& \mathrm{~s}_{\mathrm{a}}=0,114 \\
& \mathrm{~b}=0,511 \\
& \mathrm{~s}_{\mathrm{b}}=0,080 \\
& Z=\frac{0,544.0,511}{\sqrt{0,511^{2} 0,114^{2}+0,544^{2} 0,0802+0,114^{2} 0,080^{2}}} \\
& Z=\frac{0,2778}{\sqrt{0,0034+0,0019+0,0001}} \\
& Z=\frac{0,2778}{0,073281} \\
& \mathrm{Z}=3,7915
\end{aligned}
$$


Tabel 7.

Hasil Uji Sobel

\begin{tabular}{ccc}
\hline Sobel & Nilai & Keterangan \\
\hline $\mathrm{Z}$ & 3,7915 & Memediasi \\
Sig. & 0,001 & Signifikansi \\
\hline
\end{tabular}

Sumber : Data Diolah, 2018

Hasil dari pengujian variabel mediasi pada Tabel 7 yaitu kepercayaan didapatkan $\mathrm{Z}$ hitung sebesar 3,7915>1,96 dengan tingkat signifikan sebesar $0,001<0.05$ yang berarti $\mathrm{H}_{0}$ ditolak dan $\mathrm{H}_{1}$ diterima yang berarti variabel kepercayaan dinilai secara signifikan memediasi variabel pengalaman pada niat menggunakan kembali jasa JNE di Kota Denpasar.

Pengujian hipotesis pada pengaruh pengalaman terhadap kepercayaan menunjukkan bahwa pengalaman secara signifikan berpengaruh positif terhadap kepercayaan. Hal tersebut menunjukan semakin baiknya pengalaman yang diberikan oleh jasa JNE maka semakin tinggi kepercayaan dari jasa JNE di Kota Denpasar.

Pengalaman masa lalu memegang peranan penting dalam keputusan pembelian ulang konsumen. Menurut Giantari et al. (2013) pengalaman membeli secara online memiliki pengaruh positif dan signifikan terhadap kepercayaan. Hal serupa juga didapat dari hasil penelitian yang dilakukan oleh Parastanti et al. (2014) Suandana (2016), dan Mohmed et al. (2013) yang sama-sama menunjukkan pengalamanmemiliki pengaruh positif dan signifikan terhadap kepercayaan yang berarti bahwa pengalaman yang baik dalam mengonsumsi suatu produk atau jasa akan berpengaruh pada semakin tingginya tingkat kepercayaan konsumen. 
Pengujian hipotesis pada pengaruh pengalaman terhadap keputusan pembelian menunjukkan bahwa pengalaman secara signifikan berpengaruh positif terhadap niat menggunakan kembali. Hal tersebutmenunjukan semakin baiknya pengalaman yang diberikan oleh jasa JNE maka akan meningkatkan niat menggunakan kembalijasa JNE di Kota Denpasar.

Pengalaman dalam berbelanja dan mengonsumsi suatu produk tertentu akan memberikan dampak terhadap pengambilan keputusan seorang pelanggan apakah dia akan tetap menjalankan aktivitas belanjanya dengan cara tersebut atau beralih ke metode berbelanja yang lain. Menurut Weisberg et al. (2011) dan Mohmed et al. (2013) pengalaman membeli sebelumnya secara online terkait dengan niat membeli kembali secara online mempunyai pengaruh positif dan signifikan, tidak hanya dipengaruhi oleh kepercayaan dan perilaku sosial. Penelitian yang dilakukan oleh Kusumawati dan Sutopo (2013), menunjukkan bahwa customer experienceberpengaruh positif dan signifikan terhadap minat beli ulang konsumen, hal serupa juga ditunjukkan dalam penelitian yang dilakukan oleh Adytia dan Yuniawati (2015) dan Suandana (2016), yang sama-sama menunjukkan bahwa semakin baik pengalaman yang dirasakan oleh konsumen, maka semakin besar pula kemungkinan untuk melakukan pembelian ulang. Namun, penelitian lain menyatakan hal yang berlawanan, dimana menurut Giantari et al. (2013) seseorang yang memiliki pengalaman pembelian tidak selalu mendorong mereka untuk membeli kembali.

Pengujian hipotesis pada pengaruh kepercayaan terhadap niat menggunakan kembali menunjukkan bahwa kepercayaan secara signifikan berpengaruh positif 
Kadek Dwita Prabandari, Peran Kepercayaan Memediasi...

terhadap niat menggunakan kembali. Hal tersebutmenunjukan semakin baiknya kepercayaan yang dimiliki oleh jasa JNE maka akan meningkatkan niat menggunakan kembali jasa JNE di Kota Denpasar.

Kepercayaan dibentuk melalui kejujuran vendor website, keamanan data pribadi, dan jaminan pembayaran (Parastanti dkk., 2014). Dalam penelitian sebelumnya juga menunjukkan bahwa bahwa kepercayaan berpengaruh positif dan signifikan terhadap niat membeli kembali (Chinomona dan Dubihlela, 2014; Giantari dkk., 2013; Mohmed et al., 2013; Mosavi and Ghaedi, 2012; Razak et al., 2014; Rose et al., 2012; Thamizhvanan and Xavier, 2013).

Pengujian hipotesis pada peran kepercayaan dalam memediasi pengalaman terhadap niat menggunakan kembali menunjukkan bahwa kepercayaanmampu memediasi pengaruh pengalaman terhadap niat menggunakan kembali. Hal ini menunjukan kepercayaan memediasi pengaruh pengalaman terhadap niat menggunakan kemabali secara parsial,dengan kata lain kepercayaan memperkuat pengaruh pengalaman terhadap niat menggunakan kembali yang semula bernilai 0,253 namun setelah adanya kepercayaan sebagai variabel mediasi pengaruh pengalaman terhadapniat menggunakan kembali meningkat menjadi 0,530.

Hasil penelitian Weisberg et al. (2011) menemukan bahwa kepercayaan adalah sebagai variabel yang dapat memediasi hubungan pengalaman pembelian terhadap niat membeli kembali secara online. Hal senada juga disampaikan dalam penelitian Manu (2015) dan Chen (2012) dimana semakin meningkatnya kepercayaan konsumen, maka niat beli online juga semakin meningkat. Menurut Setiawan Putra dan Suryani (2015) dan Kustini (2011) kepercayaan berpengaruh 
positif dan signifikan terhadap perilaku pembelian kembali. Hasil tersebut sejalan dengan hasil penelitian yang dilakukan oleh Giantari et al. (2013) dan Suandana (2016), yang menyampaikan bahwa kepercayaan sebagai mediasi sempurna dalam pengalaman dan niat pembelian secara online. Hal tersebut berarti bahwa semakin baik pengalaman, maka semakin tinggi pula tingkat kepercayaan, dimana hal ini dapat meningkatkan niat menggunakan kembali.

Implikasi teoritis dalam penelitian ini berhubungan dengan kontribusinya bagi perkembangan konsep dalam bidang ilmu pemasaran. Hasil temuan penelitian ini memperkuat penelitian-penelitian sebelumnya yang menunjukkan bahwa pengalaman dan kepercayaan dapat mempengaruhi niat menggunakan kembali serta kepercayaandapat memediasi pengalaman terhadap niat menggunakan kembali.

Variabel pengalaman, dan kepercayaan berpengaruh positif dan signifikan terhadap niat menggunakan kembali jasa JNE di Kota Denpasar serta kepercayaan mampu memediasi pengalaman terhadap niat menggunakan kembali jasa JNE di Kota Denpasar. Untuk variabel pengalaman JNE sebagai perusahaan jasa perlu memberikan pengalaman yang menyenangkan, yang dimilikinya dimana dengan memberikan pengalaman yang membuat konsumen senangakan menambahkan daya saing yang dimilikinya dibandingkan pesaing lainnya serta dapat meningkatkan kepercayaanjasa JNE yang dapat mempengaruhi niat menggunakan kembali konsumen. Pengalaman yang baik dapat mempengaruhi niat menggunakan kembali setelah konsumen menggunakan jasa JNE, bila mampu memenuhi kebutuhan yang diperlukan oleh konsumen. 
Kadek Dwita Prabandari, Peran Kepercayaan Memediasi...

Variabel kepercayaan merupakan variabel yang perlu diperhatikan oleh JNE karena dapat mempengaruhi niat menggunakan kemabali dan pengalaman kembali terhadap niat menggunakan kembali. JNE perlu menjaga dan meningkatkan kepercayaan yang dimiliki jasa JNE agar kesan yang tertanam dibenak konsumen baik sehingga konsumen dapat merasa yakin dalam mengambil niat menggunakan kembali jasa JNE. Ketiga variabel yang diteliti memiliki keterkaitan sata sama lain sehingga JNE perlu meningkatkan kualitasnyaserta tetap menjaga kepercayaan agar kesan yang tertanam dibenak konsumen tetap baik sehingga dapat mempengaruhi niat menggunakan kembali pada konsumen.

Patut disadari bahwa terdapat beberapa keterbatasan dari penelitian ini dilakukan pada satu kurun waktu tertentu saja (cross section), sedangkan lingkungan bersifat dimanis sehingga diharapkan penelitian ini dapat dilakukan kembali di masa mendatang. Ruang lingkup serta sampel penelitian dari penelitian ini terbatas yang menyebabkan hasil penelitian tidak dapat digeneralisasi untuk konsumen di luar wilayah Kota Denpasar.

\section{SIMPULAN DAN SARAN}

Berdasarkan hasil pembahasan penelitian yang telah dilakukan, makan dapat disimpulkan bahwa pengalaman berpengaruh positif dan signifikan terhadap kepercayaan jasa JNE di Kota Denpasar. Hal tersebut bisa disimpulkan semakin baiknya pengalaman yang didapatkan oleh konsumen makan akan menimbulkan kepercayaan di benak konsumen untuk menggunakan jasa JNE tersebut.

Pengalaman berpengaruh positif dan signifikanterhadap niat menggunakan kembali jasa JNE di Kota Denpasar. Hal tersebut bisa disimpulkan semakin 
baiknya pelngalaman yang didapatkan oleh konsumen maka akan meningkatkan niat menggunakan kembali pada jasa JNE.

Kepercayaan berpengaruh positif dan signifikan terhadap niat menggunakan kembali pada jasa JNE di Kota Denpasar. Hal tersebut bisa disimpulkan semakin baiknya tingkat kepercayaan yang diberikan JNE kepada konsumennya maka akan menimbulkan niat menggunakan kembali pada jasa JNE.

Kepercayaan mampu memediasi pengaruh pengalaman terhadap niat menggunakan kembali jasa JNE di Kota Denpasar. Hal ini bisa disimpulkan bahwa kepercayaan memediasi pengaruh pengalaman terhadap niat menggunakan kembali secara parsial, dengan kata lain kepercayaan dapat memperkuat pengalaman terhadap niat menggunakan kembali pada jasa JNE.

Berdasarkan kesimpulan yang didapat, saran-saran yang dapat diberikan adalah taggapan responden pada variabel pengalaman menunjukkan bahwa indikatormendapatkan informasi merupakan indikator dalam variabel pengalaman yang memperoleh skor terendah, maka sebaiknya pihak JNE mampun memberikan informasi yang tepatdan jelas kepada konsumen, sehingga konsumen akan lebih mudah menemukan informasi yang dibutuhkannya.

Tanggapan reponden pada variabel kepercayaan menunjukkan bahwa indikatoraman dalam menggunakan produk dan percaya menggunakan produk merupakan indikator dalam variabel kepercayaan yang memperoleh skor terendah, maka sebaiknya pihak JNE lebih meningkatkan keamanan kepada konsumen saat pengiriman barang, sehingga para konsumen akan merasa aman dan percaya kepada jasa JNE bahwa barang tersebut sampai sesuai dengan tujuannya. 
Kadek Dwita Prabandari, Peran Kepercayaan Memediasi...

Tanggapan responden pada variabel niat menggunakan kembali menunjukkan indikator tidak akan berpindah merupakan indikator yang memperoleh skor terrendah dalam variabel niat menggunakan kembali, maka sebaiknya pihak JNE meningkatkan kualitas pelayanan agar konsumen JNE semakin loyal menggunakan kembali jasa JNE.

\section{REFERENSI}

Adytia, Cynthia Asrivionny and Yuniawati, Yeni. (2015). Pengaruh Customer Experience Terhadap Revisit Intention di The Trans Luxury Hotel Bandung. Tourism and Hospitality Essentials Journal, 5 (1), 2015-857.

Ardhanari, Margaretha. (2008). Customer Satisfaction Pengaruhnya Terhadap Brand Preference dan Repurchase Intention Private Brand. Jurnal Riset Ekonomi \& Bisnis, 8 (2).

Astarina, I.G.A., Giantari, I.G.A.K., dan Yasa, Ni Nyoman Kerti. (2017). Peran Kepercayaan Memediasi Pengaruh Pengalaman Terhadap Niat Menggunakan Kembali Jasa Go-Jek DI Kota Denpasar. E-Jurnal Manajemen Unud, 6 (5), 2308-2334.

Brakus, J.J., Schmitt, B.H, and Zarantonello, L. (2009). Brand Experience : What is it? How is it Meassured? Does it Affect Loyalty?. Journal of Marketing, $73(2), 52-68$.

Chinomona, R., and Dubihlela, D. (2014). Does customer satisfaction lead to customer trust, loyalty and repurchase intention of local store brands? The case of Gauteng Province of South Africa. Mediterranean Journal of Social Sciences, 5 (9), 23-32.

Chen, Yu-Shan and Ching-Hsun Chang. (2012). Enhance Green Purchase Intentions-The Roles of Green Perceived Value, Green Perceived Risk, And Green Trust. Management Decision, 50 (3), 502-520.

Diza, Farah, Moniharapon, Silcyljeova, dan Ogi, Imelda W.J. (2016). Pengaruh Kualitas Pelayanan, Kualitas Produk dan Kepercayaan Terhadap Kepuasan Konsumen (Studi Pada PT. Fifgroup Cabang Manado). Jurnal EMBA. 4 (1), 109-119.

Ghozali, Imam. (2013). Aplikasi Analisis Multivariate dengan Program IBM SPSS 2.1, Edisi. Ketujuh, Semarang: Badan Penerbit UNDIP. 
Giantari, I G.A.K., Zain, D., Rahayu, M., and Solimun. (2013). The Role of Perceived Behavioral Control and Trust as Mediator of Experience on Online Purchasing Intentions Relationship a Study on Youth in Denpasar city (Indonesia). International Journal of Business and Management Invention, 2 (1), 30-38.

Ika, Nuruni dan Kustini. (2011). Experiential Marketing, Emotional Branding, And Brand Trust And Their Effect On Loyalty On Honda Motorcycle Product. Journal of Economics, Business and Accountancy Ventura. 14 (1), 19-28.

Kusumawati, Ika Pratama and Sutopo. (2013). Analisis Pengaruh Customer Experience Terhadap Minat Beli Ulang. Diponegoro. Jurnal Manajemen, $2(2), 1-9$.

Maria-Eugenia, M., Gil-Saura, I., \& BerenguerContri, G. (2009). Relational benefits and loyalty in retailing: An inter-sector comparison. International Journal of Retail \& Distribution Management. 37(6), 493-509.

Mayer, R.C., Davis, J.H., and Schoorman, F.D. (1995). An integrative model of organizational trust. The Academy of Management Review, 20 (3): 709734.

Mohmed, A.S.I., Azizan N.B., and Jali, M.Z. (2013). The Impact of Trust and Past Experience on Intention to Purchase in E-Commerce. International Journal of Engineering Research and Development, 7 (10), 28-35.

Mosavi, S.A. and Ghaedi, M. (2012). Role of perceived value in explaining trust and repurchase intention in e-shopping. African Journal of Business Management. 6 (14), 4910-4920.

Noeraini, Irma Ayu dan Sugiyono. (2016). Pengaruh Tingkat Kepercayaan, Kualitas Pelayanan, dan Harga Terhadap Keouasan Pelanggan JNE Surabaya. Jurnal Ilmu dan Riset Manajemen. 5 (5), 2461-0593.

Nurhayati and Murti, Wahyu Wijaya. (2012). Analisis Faktor-faktor Yang Mempengaruhi Minat Beli Ulang Masyarakat Terhadap Produk Handphone. Value Added. 8 (2), 47-62.

Parastanti, GP., Srikandi, K., dan Kadarisman, H. (2014). Pengaruh Prior OnlinePurchase Experience Terhadap Trust dan Online Repurchase Intention. Jurnal Administrasi Bisnis (JAB), 16 (1): 1-7.

Pramudita, Yoana Arina, and Japarianto, Edwin. (2013). Analisa Pengaruh Customer Value dan Customer Experience Terhadap Customer 
Kadek Dwita Prabandari, Peran Kepercayaan Memediasi...

Satisfaction di De Kasteel Resto Surabaya. Jurnal Manajemen Pemasaran Petra, 1 (1), 1-7.

Prastyaningsih, Ayu S., Suyadi, Imam and Edy Yulianto. (2014). Pengaruh Customer Experience Terhadap Repurchase Intention. Jurnal Administrasi Bisnis (JAB), 16 (1).

Putra, I Putu Agus Surya Setiawan, dan Suryani, Alit. E-Jurnal Manajemen Unud, Vol. 4, No. 10, 2015: 3015 - 3036. Peran Green Trust Dalam Memediasi Green Perceived Value Terhadap Green Purchase Behavior Pada Produk Organik.

Razak, N.S.A., Marimuthu, M., Omar, A., and Mamat, M. (2014). Trust and Repurchase Intention on Online Tourism Services among Malaysian Consumers. Journal Procedia - Social and Behavioral Sciences. 130: 577582.

Riduwan \& Kuncoro. (2011). Cara Menggunakan dan Memakai Path Analysis (Analisis Jalur). Bandung: Alfabeta

Rizanata, Fahmi, Muhamad. (2014). Pengaruh Kepercayaan Pelanggan Terhadap Word of Mouth, Niat Beli dan Retensi Pelanggan Gerai Indomaret Di Surabaya. Journal of Business and Banking, 4 (1), 31-42.

Rose, S., Clark M., Samouel, P., and Hair, N. (2012). Online customer experiencein e-retailing: an empirical model of antecedent and outcomes. Journal of Retailing. 88 (2), 308-322.

Ruparelia, N., White , L., and Hughes, Kate. (2010). Drivers Of Brand Trust In Internet Retailing. Journal of Product \& Brand Management, 19 (4), 250260.

Sekaran, Uma. (2003). Research Merods For Business. New Jersey : Jhon Willey \& Sons Inc, https://iaear.weebly.com/uploads/2/6/2/5/26257106/research methods_entiree_book_umasekaram-pdf-130527124352-phpapp02.pdf, diakses pada Desember 2017.

Suandana, Ni Putu Widantari, Rahyuda, Ketut, dan Yasa, Ni Nyoman Kerti. (2016). Pengaruh Pengalaman Membeli Produk Fashion Terhadap Niat Membeli Kembali Melalui Kepuasan Dan Kepercayaan Pelanggan. Jurnal Manajemen, Strategi Bisnis, dan Kewirausahaan, 10 (1), 85-97.

Sugiyono. (2017). Metode Penelitian Bisnis Pendekatan Kuantitatif Kualitatif Kombinasi\& RND. Bandung: Alfabeta. 
E-Jurnal Manajemen, Vol. 8, No. 2, 2019: 7660 - 7687

Thamizhvanan, A., and Xavier, M.J. (2013). Determinants of customers' online purchase intention: an empirical study in India. Journal of Indian Business Research, 5, (1): 17-32.

Weisberg, J., Dov T., and Amar, L. (2011). Past Purchase and Intention to Purchase in e-commerce. The Mediation of Social Presence and Trust. Internet Research, 21 (1), 82-96.

Widiyanto, Ibnu dan Prasilowati, Sri Lestari. (2015). Perilaku Pembelian Melalui Internet. Jurnal Manajemen dan Kewirausahaan, 17,(2), 109-112. 